\title{
Wszechobecna niewidzialność. \\ Pawła Hulki-Laskowskiego tożsamość tłumacza w kontekście spolszczeń serii amerykańskich książek edukacyjnych „Cnotą a prawdą”
}

Przekładoznawstwo po zwrocie kulturowym unika kategorii błędu w dyskusji nad ,jakością" tłumaczenia, afirmuje różnicę między tekstem wyjściowym a docelowym, słusznie zauważając, że bez niej nie istniałby przekład (Hermans 36), a w konsekwencji coraz śmielej nadaje podmiotowość i sprawczość tłumaczom i tłumaczkom. Jednym z przedstawicieli tego nurtu jest Andrew Chesterman, który w artykule The Name and Nature of Translator Studies formułuje swoisty manifest subdsycypliny skupionej na badaniu nie tekstów przekładu, lecz osób je tworzących (Chesterman 16). W ramach socjologii przekładu Chesterman wyróżnia trzy ujęcia: socjologię przekładów (jako produktów na rynku międzynarodowym), socjologię tłumaczy (także rozumienie przekładu jako doświadczenia cielesnego) i socjologię tłumaczenia (procesu przekładowego). Zainteresowanie autorem (autorką) przekładu nie dotyczy wyłącznie współczesnych analiz i dowartościowania żyjących tłumaczy (tłumaczek), lecz także oznacza nowe spojrzenie na dane historyczne, bliskie archeologii tłumaczenia (Pym 18-19), czyli taki sposób uprawiania historii przekładu, który stara się wyłuskiwać $\mathrm{z}$ archiwów ślady obecności tłumaczy i tłumaczek zapomnianych, dąży do przywrócenia pamięci o ich sylwetkach, a niejednokrotnie do (od) tworzenia ich życiorysów i przywołania ich głosów do publicznej świadomości. Postanowiłam właśnie z tej perspektywy spojrzeć na rynek wydawniczy dwudziestolecia międzywojennego w Polsce, docierając do często rozproszo- 
nych i niekompletnych archiwów tłumaczy i tłumaczek. Skupiłam się na tych postaciach, które w swojej karierze podjęły się przekładu z języka angielskiego, ponieważ spolszczenia literatury angielskiej i amerykańskiej w międzywojniu ilościowo znacznie wyprzedziły przekłady literatury francuskiej czy niemieckiej (Kurowska 10), angażując tym samym najliczniejszy zastęp tłumaczy, czytelników, krytyków i wydawców (Kurowska 37-38).

Wśród tłumaczy i tłumaczek, postaci wówczas niewątpliwie istotnych, osobowości niejednokrotnie kontrowersyjnych, a dziś zupełnie (lub częściowo) zapomnianych, szczególną uwagę zwraca Paweł Hulka-Laskowski: urodzony w 1881 roku w Żyrardowie w rodzinie potomków braci czeskich - robotników miejscowej fabryki włókienniczej - pisarz, teolog, pedagog, lokalny patriota i działacz społeczny. Hulka-Laskowski, wcześnie osierocony przez matkę, już w dzieciństwie pracował w fabryce jako goniec, a wieczorami uczęszczał do gimnazjum. Samodzielnie uczył się wielu języków, między innymi greki i łaciny. Całe dorosłe życie zmagał się z chorobą płuc i postępującą głuchotą; dzięki staraniom właściciela fabryki wyjechał do sanatorium w Czechach, a następnie na studia filozoficzne i religioznawcze do Niemiec. Do końca swoich dni czuł się jednak mocno związany z rodzinnym miastem i walczył o poprawę warunków pracy robotników w Żyrardowie. Zasłynął przede wszystkim jako autor kanonicznego przekładu kultowej powieści Jaroslava Haška Przygody dobrego wojaka Szwejka podczas wojny światowej (Osudy dobrého vojáka Švejka za světové války).

Właśnie te dwa ostatnie aspekty biografii żyrardowianina sprawiły, że do dziś pielęgnuje się pamięć o nim na szczeblu instytucjonalnym: gabinet twórcy jest otwarty dla zwiedzających i stanowi oddział Muzeum Mazowsza Zachodniego w Żyrardowie, a rada rodzinnego miasta pisarza uchwaliła rok 2001 oraz 2011 latami Pawła Hulki-Laskowskiego. Autor funkcjonuje nie tylko w pamięci oficjalnej, lecz także posiada swoistych miłośników-wyznawców pielgrzymujących do Żyrardowa, redagujących amatorskie witryny internetowe poświęcone często nie tyle Hulce-Laskowskiemu, ile dobremu wojakowi Szwejkowi. Podczas lektury rozbudowanego biogramu autora przekładu czeskiej powieści antywojennej w Polskim Słowniku Bibliograficznym nie sądziłam, że tak dobrze opisana postać okaże się, przy wnikliwszym spojrzeniu, zaskakującym odkryciem.

Skalę zjawiska swoistej refrakcji pamięci i nieoczywistości upamiętnienia zrozumiałam dopiero, stykając się z archiwalnymi materiałami z jednej z wielu interdyscyplinarnych konferencji naukowych organizowanych wokół postaci Hulki-Laskowskiego przez Parafię Ewangelicko-Reformowaną w Łodzi we współpracy z Zakładem Filozoficznych Podstaw Pedagogiki Wydziału Pedagogicznego Uniwersytetu Warszawskiego, Wydziałem Teologicznym Chrześcijańskiej Akademii Teologicznej oraz Towarzystwem Pedagogiki Filozoficznej 
im. B.F. Trentowskiego. Wydarzenie pod znamiennym tytułem: „Paweł Hulka-Laskowski - pisarz, religioznawca, bibliofil, pedagog” odbyło się w kościele ewangelicko-reformowanym w Łodzi w 2015 roku. Organizatorzy w sprawozdaniu po konferencji w następujący sposób opisywali wnioski i wrażenia z konferencji:

Twórczość [Pawła] Hulki[-Laskowskiego], jeśli w ogóle jest z czymś kojarzona, to najczęściej z jego pracą translatorską, a zwłaszcza z przetłumaczeniem przez niego Przygód dobrego wojaka Szwejka, zupełnie tak, jakby to był jedyny wkład żyrardowianina w kulturę polską. Konferencja łódzka ukazała natomiast imponującą różnorodność zainteresowań Laskowskiego, wydobywając na światło dzienne te wymiary jego działalności i pracy naukowej, które we wcześniejszych badaniach były pomijane lub mało akcentowane. Na przykład, zupełną nowością są zaprezentowane w Łodzi wyniki badań nad poglądami filozoficzno-religijnymi Hulki oraz jego aktywnością na polu pedagogiki. Jak więc widać, łódzkie spotkanie w istotny sposób poszerzyło wiedzę o Pawle Hulce-Laskowskim (Tys, Leszczyński 222).

Autorzy sprawozdania, oceniając przebieg wydarzenia, uznali, że główny cel konferencji, czyli „holistyczne spojrzenie na biografię i dorobek Pawła Hulki-Laskowskiego" (Tys, Leszczyński 222) został w pełni osiągnięty. Wśród paneli historycznych, filozoficznych, pedagogicznych, teologicznych, poświęconych stosunkom dyplomatycznym między Polską a Czechami, a nawet bibliofilskich, pojawił się tylko jeden referat dotyczący przekładu (z języka czeskiego, czego nie zasugerowano w tytule, uznając to prawdopodobnie za oczywiste): „Polszczyzna tłumaczeń Pawła Hulki-Laskowskiego a język polski pierwszej połowy xx w.." Biorąc pod uwagę fakt, że Hulka-Laskowski zostawił po sobie nie tylko przekłady z wielu języków: czeskiego, niemieckiego, francuskiego, rosyjskiego, duńskiego i, z perspektywy mojej analizy najbardziej interesującego, angielskiego, lecz także artykuły publicystyczne (w językach: polskim, francuskim, niemieckim i czeskim - bibliografia Bara notuje aż 1739 pozycji) sygnowane licznymi pseudonimami, trudno uznać obraz intelektualisty i pedagoga wyłaniający się z programu łódzkiej konferencji za kompletny.

Łódzka narracja wydaje się bardzo symptomatyczna dla sposobu, w jaki nadal traktuje się tłumaczy i tłumaczki w debacie publicznej. Nie mam zamiaru deprecjonować wymienionych przez organizatorów konferencji aktywności Hulki-Laskowskiego na innych polach ani samej idei kultywowania jego pamięci; chciałabym raczej spojrzeć na ogół działań twórcy i reformatora przez pryzmat tak chętnie ignorowanego w powszechnym dyskursie przekładu i zaproponować 
możliwe odpowiedzi na pytanie, dlaczego wciąż w obiegowej opinii tłumacz jest instancją odtwórczą, podporządkowaną „prawdziwemu” autorowi (tj. autorowi oryginału), a więc, jeśli to możliwe, kompletnie pomijaną.

Hulka-Laskowski pozostawił po sobie nie tylko publikacje z zakresu pedagogiki, filozofii i teologii, lecz także, z perspektywy historyków przekładu, tom wyjątkowo istotny: autobiografię Mój Żyrardów. Z dziejów polskiego miasta $i \dot{z} y$ cia pisarza. Autor w osobistych wspomnieniach opowiada nie tylko o małej ojczyźnie i wielkiej historii, lecz także o własnych losach: pułapkach wychowania, samodzielnej nauce języków i wreszcie doli tłumacza w pierwszych dekadach xx wieku. Książka, wydana po raz pierwszy w 1934 roku, stanowi wyjątkowo drobiazgowy i niezapośredniczony cudzą narracją zapis losów tłumacza; trudno o równie kompletny materiał archiwalny dotyczący którejkolwiek z tłumaczek tego okresu. Na popularność dzieła i jego rozpowszechnienie (najnowsze wznowienie pochodzi z 2001 roku dzięki Oddziałowi Muzeum Mazowsza Zachodniego w Żyrardowie) mógł wpłynąć tytuł, paradoksalnie rugujący tożsamość tłumacza z okładki. Nie bez znaczenia jest także płeć Hulki-Laskowskiego: pisarz, pedagog i dyplomata to profesje, które w powszechnej świadomości „naturalnie” przynależą mężczyźnie, nadają mu prestiżowy status i władzę, cechy wciąż rzadko kojarzone ze „służebną”, „odtwórczą” pracą osoby (najczęściej kobiety) odpowiedzialnej za przekład (Jarniewicz 80-83).

Już na pierwszych stronach autobiografii żyrardowianina czytelniczce ukazuje się obraz człowieka ciekawego świata, zdeterminowanego do nauki, niepokornego, przekonanego o potędze wiedzy, a przede wszystkim: zafascynowanego materią języka. Wychowany w duchu ewangelickiej surowości i podporządkowania, Hulka-Laskowski samodzielnie stara się znaleźć odpowiedzi na nurtujące go pytania, wykraczając poza karną pobożność. Ważnym wątkiem w autobiografii są zatem inicjacje. Pierwszym przebłyskiem wtajemniczenia jest dla tłumacza nauka czytania:

[...] ostatecznie czytać się nauczyłem. Przyszło to pewnego dnia samo $\mathrm{z}$ siebie i wtedy uciesze nie było końca. Ponieważ książek w domu nie mieliśmy zbyt wiele, więc sztukę czytania sprawdzałem przy każdej sposobności na każdym skrawku znalezionej gazety. I wtedy polubiłem sklep pana Niebrzydowskiego, do którego matka posyłała mnie po herbatę, kawę, mydło, cukier, naftę i cykorię. [...] pan Niebrzydowski zawijał cały sprawunek w karty starych gazet. Dopieroż było czytania! Ostrożnie rozwijałem w domu paczkę, wygładziłem kartę gazety, a potem czytałem o mnóstwie rzeczy obcych, niezrozumiałych i niepokojących. Świat był pełen tajemnic, w gazetach pisano o rzeczach 
dziwnych i nieznanych. Coby znaczyły te rzeczy, nie było kogo zapytać, musiałem je tedy tłumaczyć je sobie na swój sposób. Na jednej z kartek przeczytałem, na przykład, kilka niezrozumiałych zdań o Boskiej Komedii Dantego. Ktoby był ten Dante, z takiem śmiesznem nazwiskiem, mało mnie obchodziło, ale komedia i to boska, to już była sprawa godna zainteresowania (Hulka-Laskowski 20o1: 46).

Umiejętność czytania, uważana w rodzinie robotniczej za zbędną, a wręcz szkodliwą, niezwykle frapowała chłopca, nie zaspokoiła jednak jego ciekawości, lecz przyczyniła się do jej pełniejszego rozbudzenia. Stała się pierwszym krokiem do nałogu zdobywania nowej wiedzy, a w konsekwencji, utraty niewinności. W przytoczonym fragmencie pobrzmiewa także perspektywa, z której autor opisuje swoje dziecięce wspomnienia. Dystans czasowy oddzielający spragnionego wiedzy chłopca od doświadczonego mężczyzny, który o tym chłopcu z krytyczną czułością opowiada, a zwłaszcza rola, jaką przypisuje się słowom, przywodzi na myśl narrację pisarki i historyczki Evy Hoffman'1. Na etapie wyrywkowej, przypadkowej, dziecięcej (nieświadomej, a więc: niewinnej) lektury fragmentów Boskiej Komedii Dantego trudno doszukiwać się natłoku „rzeczy obcych, niezrozumiałych i niepokojących" (Hulka-Laskowski 2001: 46), które takimi miały okazać się w przyszłości.

Ważnym wątkiem obecnym we wspomnieniach Hulki-Laskowskiego jest analiza odebranego wychowania i próba zbadania jego wpływu na dorastanie młodych ludzi na ziemiach polskich pod koniec XIX wieku. W tym kontekście tłumacz wspomina o opresji, jaką generowało chrześcijańskie przysposobienie do życia w atmosferze nieustannego poczucia winy i czujności, lęku przed grzechem, oraz o spustoszeniu, jakie siało wpajane dzieciom przekonanie, że występkiem przeciwko woli Boga jest także chęć realizacji swoich ambicji - jedna z możliwych kontynuacji grzesznej ciekawości:

Niestety, człowiek wychowany w konwencjonalnej szkole przedwojennej, czy powojennej, na nic innego poza marzeniem zdobyć się nie umie.

1 Eva Hoffman w autobiograficznej powieści Lost in Translation napisanej z perspektywy wykształconej na amerykańskich uniwersytetach wziętej badaczki zdradza inspiracje psychoanalizą, opisując losy swojego dzieciństwa. Urodziła się w Krakowie jako Ewa Wydra, jednak w momencie emigracji do Ameryki Północnej rozpoczęła długotrwały i trudny, acz konieczny proces „przetłumaczenia siebie”. Jednym z kluczowych momentów tego procesu był swoisty „chrzest” w kanadyjskiej szkole, przybranie imienia Eva (por. Hoffman). 
Szkoła wypacza w nim zdrowy instynkt życia, odbiera aktywność egoizmu i wpaja rezygnację jako najwyższą postać cnoty chrześcijańskiej. [...] Na każdym kroku, w szkole, w kościele, w domu, słowo żywe i nieżywe nauczało i nakazywało: bądź ubogi, nie pragnij niczego, jeśli chcesz dostać się do królestwa bożego i być kochanym przez Boga! [...] Młodzieniec uczył się robić mniej lub więcej zgrabne wierszyki, stawał się wreszcie prezesem stowarzyszenia mandolinistów, ale nawet przez myśl mu nie przeszło, aby stać się dyrektorem, fabrykantem, bogaczem (Hulka-Laskowski 2001: 148-149).

W powyższym fragmencie uderza jeszcze jedna cecha pisarstwa Hulki-Laskowskiego, wyraźna zwłaszcza w jego krótszych tekstach publicystycznych: cięty język i ironiczne poczucie humoru przejawiające się przede wszystkim w kompromitacji utartych fraz liturgicznych, rekontekstualizacji i testowaniu ich znaczeń w nowych okolicznościach. Powyższa tendencja świadczy o ponadprzeciętnej wrażliwości na słowo, jego brzmienie i konotacje, tak ważnej w pracy tłumacza. Znajomość języków obcych, czyli nieustanne wykraczanie ponad ogólnie przyjętą przeciętność, dodawała Hulce-Laskowskiemu coraz więcej prestiżu (sprawiała, że zlecono mu przekład między innymi tekstu czeskiej konstytucji dla Ministerstwa Spraw Zagranicznych (Hulka-Laskowski 2001: 221) oraz innych oficjalnych doniesień politycznych zza granicy), który bardzo rzadko szedł w parze $\mathrm{z}$ rosnącym wynagrodzeniem. Mimo dużego poważania w najbliższym otoczeniu i wśród współpracowników przekład nie zapewniał tłumaczowi stabilności finansowej. Sytuacja tłumacza w dwudziestoleciu międzywojennym, nieobca osobom zawodowo zajmującym się przekładem także współcześnie, była trudna i frustrująca, z powodów finansowych nieomal eliminowała swobodę wyboru zleceń; jak wspomina Hulka-Laskowski: „Tłumaczenie papierów handlowych i stylizowanie sprawozdań przemysłowych dawało daleko więcej, niż tłumaczenie książki o świętym Franciszku albo felietonów Machara z jego podróży do Rzymu" (Hulka-Laskowski 2001: 244). Jak w swoim studium recepcji literatury angielskiej w Polsce w latach trzydziestych zauważa Elżbieta Kurowska, rynek wydawniczy tego okresu gwałtownie się powiększał, a równocześnie nie podlegał żadnej odgórnej kontroli (Kurowska 58-59): wydawcy zdarzało się zaprzepaszczać wiele godzin pracy tłumacza, rezygnując z wydania przygotowywanej publikacji bez wypłacania mu choćby zaliczki; często decydowano się na wybór osoby nie najbardziej kompetentnej, lecz takiej, która zobowiązała się wykonać przekład najtaniej i/lub najszybciej. Trudną i niepewną dolę tłumacza Hulka-Laskowski kwituje gorzką refleksją: 
Przyjmowałem każdą nadarzającą się pracę i przesiadywałem przy maszynie do pisania po kilkanaście godzin dziennie. Zresztą pracować lubiłem i robota stawała się dla mnie nałogiem, niestety, rujnującym. Kaligraficzny wzorzec szkolny, opiewający, że „cierpliwością i pracą się ludzie bogacą" był nieścisły, bo nie mówił czyją pracą i kto się bogaci. Ja od własnej pracy ubożałem. Miałem jej coraz więcej, ale zarobki coraz mniejsze (Hulka-Laskowski 2001: 244).

Wzrost ilości zleceń w danym okresie nie dawał żadnej gwarancji stabilizacji. Stąd pracowity i ambitny tłumacz mógł nieopatrznie wpaść w wir pracy, która nigdy się nie kończy. Jak wspomina Hulka-Laskowski:

Tłumaczyłem z niemieckiego, francuskiego, czeskiego co kto chciał, byle zarobić trochę pieniędzy i powetować do pewnego stopnia wielkie szkody, jakie przyniosła z sobą wojna. Przekładałem Fenimora Coopera, Hauffa, sentymentalnego Bonselsa, książki pedagogiczne, eugeniczne, okultystyczne i Bóg wie, co tam jeszcze. Spolszczyłem całe dziesiątki tomów i czekałem cierpliwie na skutki. Wszystko wlot wydawano, ale łatwiej było bardzo grubo zarobić, niż otrzymać skromniutką zaliczkę (Hulka-Laskowski 2001: 244).

Skrajna niestałość pracy tłumacza w dwudziestoleciu międzywojennym sytuacja typowa dla przedstawicieli prekariatu również sto lat później - nie oznaczała jednak, że wybory translatorskie Hulki-Laskowskiego były zupełnie przypadkowe lub podyktowane wyłącznie chęcią zarobku. Oprócz spolszczenia wspomnianych powieści przygodowych J.F. Coopera (wśród których najbardziej znaną jest Ostatni Mohikanin), tłumacz podjął się przekładu i adaptacji pewnej serii książek edukacyjnych z języka angielskiego napisanych przez amerykańskiego pastora Sylwanusa Stalla oraz lekarkę i działaczkę społeczną Mary Wood-Allen na przełomie wieków XIx i xx. Oryginalna seria, składająca się z 8 tomów (4 dla chłopców i mężczyzn, 4 dla dziewcząt, panien i kobiet), w Polsce ukazała się w okrojonym, sześciotomowym wydaniu ${ }^{2}$ w latach dwudziestych xx wieku nakładem łódzkiego ewangelickiego Towarzystwa Wydawniczego

2 W Polsce ukazały się następujące książki z tej serii: O czem każda panna wiedzieć powinna, O czem młoda mężatka wiedzieć powinna, O czem każda dziewczynka wiedzieć powinna oraz $O$ czem każdy chłopiec wiedzieć powinien, O czem młody człowiek wiedzieć powinien i O czem każdy małżonek wiedzieć powinien. Dwie brakujące, które nie doczekały się wydania, to pozycje poświęcone ludziom w średnim wieku: What a Man 
„Kompas” pod wspólnym tytułem: „Cnotą a prawdą”. Jak zapewnia wydawca na czwartej stronie okładki, seria „wydana w 24 językach [...] rozeszła się po całym świecie w milionach egzemplarzy”, trudno jednak zakładać, że nadrzędną motywacją do przekładu tej serii miałyby być względy finansowe ${ }^{3}$. Cykl w całości przetłumaczony i opracowany przez Hulkę-Laskowskiego porusza szereg tabuizowanych ówcześnie (a niekiedy także obecnie) tematów, włączając w ich poczet masturbację, prostytucję czy choroby weneryczne. Tom II serii, skierowany do młodych mężczyzn, o znamiennym tytule: O czem młody człowiek wiedzieć powinien ${ }^{4}$, zawiera, w przeciwieństwie do pozostałych woluminów, przedmowę dodaną wyłącznie do polskiego wydania, tłumaczącą powody, dla których zdecydowano się na publikację na rodzimym gruncie:

W literaturze naszej tak zasobnej w powieści dobre i liche, brak zupełnie dzieł, które mogłyby służyć jako drogowskaz dla niedoświadczonej łatwo błądzącej młodzieży. Zdarza się niejednokrotnie, że, gdy taki młodzian, idąc samopas życiem, nabawi się nieszczęścia, jakie przedstawia choroba weneryczna, i traci cierpliwość, jeśli kuracja trwa przydługo, to dowiaduje się od lekarza tego wszystkiego, co powinien był wiedzieć już dawno, aby mógł uniknąć nieszczęścia (Stall 3).

Choć oficjalnym nadawcą przedmowy jest wydawca, retoryka oraz styl wypowiedzi wskazują na bliskie pokrewieństwo z myślą i poglądami samego tłumacza (który zresztą miał nie tyle przetłumaczyć, ile „opracować”5 serię na potrzeby polskich odbiorców i odbiorczyń). Hulka-Laskowski wielokrotnie na łamach pracy codziennej i periodyków specjalistycznych piętnował pruderię i dulszczyznę polskiego społeczeństwa, w tekstach publicystycznych i teologicznych postulował większą otwartość obyczajową i szczerość w debacie publicznej, narażając się tym samym na ataki ze strony środowisk konserwa-

of Forty-five Ought to Know oraz What a Man of Forty-five Ought to Know (sygnowana przez Emmę Frances Angell Drake).

3 Z dużym prawdopodobieństwem należy przypuszczać, że publikacja ta była propagowana niekomercyjnie wśród ewangelickich parafii. Nie zachowały się żadne recenzje ani wzmianki serii „Cnotą a prawdą” w popularnych periodykach, co sugerowałoby niszowy charakter publikacji.

4 Tytuł zarówno oryginalnej publikacji: What a Young Man Ought to Know, jak i jej spolszczenia ujawnia patriarchalny i fallocentryczny rys zakładający, że synonimem słowa „człowiek” jest „mężczyzna”.

5 Skala ingerencji w tekst angielski i jej ewentualnych rezonansów w recepcji serii w Polsce wymaga dalszych badań. 
tywnych. Z tej perspektywy, akt przekładu serii książek adresowanej pierwotnie do amerykańskiej młodzieży można postrzegać przede wszystkim jako chęć transferu nowoczesnych i kontrowersyjnych treści na grunt II Rzeczpospolitej, przesiąknięty w większości narracją konserwatywną połączoną z tradycją i obyczajowością chrześcijańską (zwłaszcza w jej, zdaniem Hulki-Laskowskiego, najgorszej, katolickiej odmianie) ${ }^{6}$.

Na potwierdzenie tezy o tym, że opracowanie spolszczeń serii „Cnotą a prawdą" przez Hulkę-Laskowskiego podyktowane było względami osobistymi, warto przytoczyć fragment wspomnień zawarty w autobiografii. Autor wprost wyznaje, jak szokująca była dla niego konfrontacja ewangelickiej moralności wyniesionej z domu z rzeczywistością, o której czytał w autobiograficznej publikacji autorstwa Josefa Svatopluka Machara napisanej i wydanej po czesku - możliwa tylko i wyłącznie dzięki lekturze oryginału (czyli dzięki temu, że Hulka-Laskowski władał czeszczyzną). Czytając o życiu uczuciowym i erotycznym czeskiego pisarza, poety i polityka, Hulka-Laskowski poznawał niedostępny mu dotąd, nieistniejący w jego polszczyźnie (a więc: w jego rzeczywistości) świat ziemskich rozkoszy. Do znacznie bardziej bezpośredniej i dosłownej inicjacji na tym polu doszło, niewiele później, również za sprawą przekładu. Hulka-Laskowski, już jako kilkunastoletni chłopiec, władający także językiem niemieckim, zyskał prestiż wśród gorzej wykształconych, a często starszych od siebie robotników fabryki w Żyrardowie. Uchodził w swoim środowisku za eksperta, pośrednika, mediatora, pomocnika (warto zwrócić uwagę, że każde z tych określeń może stanowić synonim słowa „tłumacz”), a więc za osobę godną zaufania; taką, której można powierzyć najskrytsze sekrety, a być może także taką, u której zaciąga się dług wdzięczności. Tłumacz, wracając wspomnieniami do lat młodzieńczych, w następujący sposób opisuje sytuację, która przydarzyła mu się pewnego wieczoru w pokoju zaprzyjaźnionego robotnika:

Miałem mu coś przetłumaczyć z niemieckiego, bo się uczył tego języka i niebardzo mu szło. Poszedłem i tłumaczyłem, jak się dało. W pewnej chwili do drzwi jego kawalerskiego pokoiku ktoś puknął trzy razy. Mój gospodarz zrobił minę tajemniczą, przyłożył palec do ust, ujął mnie za rękę i na palcach podprowadził do parawanu okalającego kuchenkę. Wskazał mu krzesło i kazał być cicho. Siedziałem tedy za parawanem z trudem opanowując szczękanie zębów. Do pokoiku weszła znajoma pani [...] i bardzo sprawnie przystąpiła do rzeczy. Mój gospodarz przy-

6 Więcej o Pawła Hulki-Laskowskiego krytyce Kościoła katolickiego w kontekście Polski zob. Rosica. 
gasił lampę, a pani oświadczyła: „Zimno tu jak w psiarni, rozbierać się nie będę, a zresztą trzeba się spieszyć, bo nie mam czasu...”. Drżałem ze strachu i odmawiałem pacierze, bo byłem święcie przekonany, że za chwilę jasny piorun uderzy w żelazne łóżko, które skrzypiało przeraźliwie. Nie uderzył. Pani się spieszyła, obiecała przyjść jutro i poszła. Mój gospodarz wyprowadził mnie zza parawanu i bardzo uprzejmie zapytał, czy ją chcę. Nie chciałem oczywiście, bo się strasznie bałem swej ciekawości. To może inną? I innej też nie chciałem. Byłem uświadomiony i wiedziałem teraz, że codzienne rozmowy przy biurku nie są zmyśleniem. Pukanie do drzwi, parawan, przykręcanie lampy, skrzypienie łóżka... - wszystko było takie proste, a mnie się wydawało zawsze, że to coś niesłychanego (Hulka-Laskowski 2001: 125).

Owo nieproszone i nieoczekiwane „uświadomienie” nie tylko ujawniło przed Hulką-Laskowskim sfery życia, których wcześniej do siebie nie dopuszczał, lecz także podsyciło paraliżującą ciekawość, interpretowaną w nurcie chrześcijańskim jako zagrożenie, „pierwszy stopień do piekła”. Do podobnej konfrontacji wychowania z rzeczywistością dochodziło (właśnie dzięki przekładowi) jeszcze wielokrotnie w dorosłym życiu Hulki-Laskowskiego.

Zjawisko osobistego, zaangażowanego przekładu, które możemy zaobserwować w geście spolszczenia serii „Cnotą a prawdą”, zasługuje na uwagę również dlatego, że z perspektywy pierwszych książek poświęconych wychowaniu seksualnemu dzieci i młodzieży wydanych na ziemiach polskich, które ukazały się kilka dekad wcześniej (Sikorska-Kulesza 25), gest Hulki-Laskowskiego można traktować jako osobisty manifest. Tłumaczowi wielokrotnie zarzucano zbyt dużą otwartość i bezpośredniość w wypowiedziach, czemu dają wyraz liczne polemiki na łamach ówczesnej prasy. Nie dotyczą one jednak wyłącznie treści, lecz także formy, sposobu komunikowania rewolucyjnych postulatów. Wypowiedzi publicystyczne tłumacza cechuje wyrazistość poglądów i bezkompromisowość. Hulka-Laskowski nie tylko piętnował obłudę i opowiadał się za postępem, lecz także wprost formułował liczne postulaty socjalistyczne i feministyczne. W podobnym duchu można interpretować dalszy ciąg przedmowy do drugiego tomu analizowanej serii:

Do niedawna uchodziło za wykroczenie przeciwko dobremu tonowi mówienie i pisanie o pewnych rzeczach. Dobry ton był zachowywany, ale ludzie ginęli. Rzucono sobie tedy pytanie, czy nie lepiej poświęcić bałwana dobrego tonu, aby ratować ludzi. Okazało się, że nawet dobremu tonowi nie stanie się żadna krzywda, gdy za rzecz weźmie się 
człowiek szlachetny i roztropny. Przykładem tego jest niniejsza książka, która w sposób poważny i szlachetny poucza o tem, o czem wszyscy wiedzieć powinni pod grozą narażenia się na wielkie nieszczęście (Stall 8-9).

Warto w powyższym fragmencie zwrócić uwagę na grę z odbiorcą: dość dwuznaczny sposób, w jaki przywołano autorytet „człowieka szlachetnego i roztropnego" - pochwały te mogą odnosić się zarówno do amerykańskiego pastora, jak i polskiego tłumacza, autora zaadaptowanej na potrzeby nowej publiczności treści. Ów fragment stanowi także przejaw swoistej, często niezauważanej, władzy tłumacza: prawa do przemycenia kontrowersyjnych lub wręcz nieakceptowalnych w kulturze docelowej treści „tylnymi drzwiami”, właśnie poprzez przekład. Hulka-Laskowski w tekstach publicystycznych otwarcie popierał osobliwą rewolucję językową Tadeusza Boya-Żeleńskiego, pochwalał bliskość życia w języku, potoczność, dosłowność, dosadność, a niekiedy wręcz wulgarność przekładów mistrza; $\mathrm{w}$ jednym $\mathrm{z}$ felietonów o znamiennym tytule Boy-mędrzec czytamy jawną krytykę konserwatywnego, fałszywego i cenzurującego podejścia do literatury i kultury słowa w ogóle: „Istnieją jeszcze mamuty, które biedzą się wątpliwościami, czy wolno w towarzystwie mówić o skarpetce i czy w druku nie należy wykropkować słowa "pępek»" (Hulka-Laskowski 1928b: 3). Hulka-Laskowski kompromitował obawy konserwatystów nie tylko używając hiperbolizacji i chwytów retorycznych w polemikach i artykułach, lecz także stosując logiczną argumentację popartą konkretnymi przykładami: najczęściej poruszał tematy związane z rolą kobiet w społeczeństwie i w kościele, z niebezpieczeństwami katolicyzmu jako bezrefleksyjnie przyjmowanego modelu wartości, wyzwaniami współczesności (zwłaszcza międzykulturowością, kondycją człowieka w drugiej dekadzie xx wieku, nowoczesnością): w przytoczonym już peanie na cześć Boya-Żeleńskiego Hulka-Laskowski następująco ocenia działalność przekładową krytyka i eseisty: „Boy lekarz stawał się [...] prawnikiem, aby wyprocesować sobie prawo do słów takich jak zdziry, dziwki, lesbijki rozumiejąc, że wykropkowanie tych rzeczy to niebezpieczeństwo nowych powikłań i kompleksów freudowskich" (Hulka-Laskowski 1928b: 3). Opinia ta, odznaczająca się nie tylko brawurową retoryką, lecz także swoistą performatywnością (jako że realizuje formułowane postulaty), idealnie współbrzmi z przedmową do drugiego tomu serii „Cnotą, a prawdą”. Hulka-Laskowski wierzył, że - w myśl poglądów Ludwiga Wittgensteina - granice języka są granicami świata, a próba przemilczenia niewygodnych i trudnych treści nie wyeliminuje ich z rzeczywistości, lecz jedynie powiększy repertuar kwestii tabuizowanych, a w konsekwencji społecznego wykluczenia tych, którzy dopuścili się tego, o czym nie można nawet mówić. 
Hulka-Laskowski nie traktował jednak przekładu wyłącznie utylitarnie, jako lekarstwa na bolączki pruderyjnego społeczeństwa; odznaczał się wrażliwością na słowo i kontekst oryginału; w tomie wspomnieniowym dokonuje refleksji nad dynamiką swojej kariery tłumacza oraz opisuje ewolucję własnego warsztatu. Debiut przekładowy był dla niego cenną lekcją pokory; jak pisze:

[...] moje tłumaczenie było złe, musiało być złe, bo zabierałem się do tej pracy zgoła nieprzygotowany i nie mający pojęcia o języku literackim, ale ostra krytyka bardzo mnie zabolała. Zrozumiałem, że będę musiał uczyć nawet takich rzeczy, które uważałem zgoła za elementarne. (Hulka-Laskowski 2001: 144).

Na przestrzeni trzydziestu lat praktyki przekładowej Hulka-Laskowski nie tylko wyrobił własny styl, ale także wykształcił w sobie umiejętność rzeczowej polemiki dzięki świadomości własnych oczekiwań i możliwości. Jako doświadczony tłumacz wiedział, do czego dąży, potrafił rozpoznać i wykazać, kiedy zarzuty pod adresem jego przekładu nie są merytoryczne, lecz podyktowane innymi, przeważnie politycznymi, pobudkami. W słynnym artykule $O$ dyskwalifikację tłumaczenia opublikowanym na łamach „Wiadomości Literackich” Hulka-Laskowski opisuje proces dochodzenia do prawdy, czyli wytrwałe i nieustępliwe odwoływanie się od decyzji Komisji do Oceny Książek do Czytania dla Młodzieży Szkolnej, która uznała jego przekład czeskiej powieści za niegodny publikacji. Jak się okazało, prawdziwą przyczyną nie były insynuowane tłumaczowi niedostatki warsztatu, lecz względy obyczajowe. Co roku wznawiana w Czechach „Babunia” miała być, zdaniem Komisji, zbyt odważna dla polskiej młodzieży (Por. Hulka-Laskowski 1928a: 4). Hulka-Laskowski buntowniczo konstatuje w polemice: „Wartość swego tłumaczenia znam i nie obawiam się sądów językoznawców i stylistów"(Hulka-Laskowski 1928a: 4) i nie poprzestaje na deklaracjach: przez kolejne tygodnie szuka na forum prestiżowego periodyku sojuszników, wzywa opinię publiczną do zabrania głosu, a następnie brawurowo odpiera zarzuty, odnosząc się do każdego z wytkniętych mu skrupulatnie (dwudziestu jeden) błędów, i wyjaśnia, jak krzywdzące dla poszczególnych przedstawicieli profesji przekładowej i równocześnie szkodliwe dla całego środowiska tłumaczy są bezpodstawne oskarżenia kierowane pod adresem „niewygodnych” przekładów; zaznacza: „Jako pisarz uprawiający rzemiosło literackie niemal 30 lat, znam język polski dobrze i na gołosłowne orzeczenie komisji zgodzić się nie mogę" (Hulka-Laskowski 1928a: 4). Jak, nieco ironicznie, stwierdza w jednej z późniejszych polemik: „Komisja zaliczyła mi więc szereg klasycznych zwrotów polskich jako błędy językowe, tylko dlatego, że zwroty te nie były jej znane" (Hulka-Laskowski 1928c: 4). 
Hulka-Laskowski dawał wyraz ogromnej samoświadomości tłumacza jeszcze wielokrotnie: potrafił odeprzeć - często impresyjne lub skrajnie subiektywne (podyktowane bardziej pobudkami światopoglądowymi niż literackimi) - zarzuty konkretnych czytelników i czytelniczek, broniąc tym sposobem prywatnej polityki przekładu, czyli wartości, które przyświecały mu w pracy przekładowej. Odnosząc się do listu jednej z oburzonych czytelniczek przekładu Przygód dobrego wojaka Szwejka..., która oskarżyła go o nieparlamentarne słownictwo i błędy rzeczowe, Hulka-Laskowski zauważa, że miała ona „mocne podejrzenie, że to nie Szwejk jest urzędowym idiotą, ale autor razem z tłumaczem" (Hulka-Laskowski 1929: 4), i wyjaśnia: „Tłumacz nie ma najmniejszego prawa poprawiać autora, ale może go co najwyżej tłumaczyć" (Hulka-Laskowski 1929: 4). Można zatem przyjąć, że Hulka-Laskowski starał się w miarę możliwości nie tylko tłumaczyć obcojęzyczne powieści, lecz także tłumaczyć odbiorcom przekładu specyfikę pracy przekładowej lub przynajmniej cierpliwie i nieustępliwie ją przybliżać (także za pomocą perytekstów, które pomijano w lekturze`). Jego poglądy w tej kwestii i dziś mogą być źródłem wiedzy o ówczesnej kulturze, swoistym świadectwem danej epoki. Niewątpliwie stanowią natomiast manifest stylu i światopoglądu autora.

Jak starałam się pokazać, doświadczenie przekładu na trwałe wpłynęło na prywatną i zawodową biografię Hulki-Laskowskiego. Przez bogatą literacką i publicystyczną spuściznę pisarza prześwieca głęboka więź z językami obcymi i z przekładem. Nie tylko czeski czy niemiecki, lecz także rosyjski, francuski i w końcu angielski były dla niego szansą na poszerzenie wiedzy i przeżycie tego, czego na ziemiach polskich pod zaborami, a następnie w granicach niepodległej już ojczyzny nie byłby w stanie doświadczyć. Losy Hulki-Laskowskiego są dowodem na to, że życie tłumacza bywa w całości zdeterminowane przez przekład, który jako praktyka nie tyle językowa, ile kulturowa czy wręcz egzystencjalna, wpływa na wszystkie dziedziny życia i (współ)tworzy wielopłaszczyznową tożsamość. Hulka-Laskowski: robotnik, żyrardowianin, ewangelik, publicysta, pisarz, teolog, dyplomata, moralizator, chory, feminista, w żadnej z powyższych ról nie przestawał być tłumaczem; ponadto niektóre z jego aktywności stały się możliwe lub konieczne właśnie dzięki przekładowi. Można przypuszczać, że pedagog niemający translatorskiego warsztatu szukałby pośredników, którzy dotarliby do projektowanej publiczności, lub innych dróg prezentacji własnych poglądów. Hulka-Laskowski mógł natomiast aktywnie i świadomie inicjować

7 Taką tezę stawia sam Hulka-Laskowski, zauważając, że oburzenie „pewnej Pani z Krakowa”, która najwyraźniej zignorowała przedmowę do Przygód dobrego wojaka Szwej$k a . . .$, niewątpliwie o tym świadczy (Hulka-Laskowski 1929: 4). 
i wspierać transfer nowoczesnych, niekiedy niewygodnych i kontrowersyjnych, idei. Co więcej, to właśnie przekład doprowadził do pierwszych wtajemniczeń i inicjacji w jego prywatnym życiu, które być może wpłynęły na tak krytyczny stosunek tłumacza do konserwatywnego wychowania, a w konsekwencji mogły doprowadzić do chęci zmiany języka opisu doświadczenia dorastania.

Ogromna ciekawość świata, determinacja, dociekliwość i wytrwałość to cechy, które pozwoliły Hulce-Laskowskiemu szlifować warsztat tłumacza: oddać się kapryśnej pasji i trudnej profesji. Przekład był jednak dla żyrardowianina nie tylko pracą zarobkową, w ramach której walczył o godne warunki życia i szacunek opinii publicznej, lecz także sposobem na życie, misją: tłumacz pragnął naprawić szkody wojenne, zdobyć wiedzę, by następnie dzielić się nią z tymi, którzy z różnych przyczyn nie mieli do niej dostępu. Doświadczenie i samoświadomość sprawiły, że z mocą mógł bronić własnych tez i odpierać bezpodstawne lub podyktowane politycznymi przesłankami zarzuty. Odkrywając portret dojrzałego tłumacza, trudno pogodzić się z obiegową opinią, w której aktywność przekładowa jest marginalizowana. Zastanawiając się nad źródłami tendencji do pomijania tożsamości tłumacza w powszechnej refleksji nad dorobkiem Pawła Hulki-Laskowskiego, doszłam do wniosku, że, paradoksalnie, takie działanie umożliwia sama specyfika aktywności przekładowej. Hulkę-Laskowskiego można by bowiem nazwać tłumaczem w ujęciu Anthony’ego Pyma. Badacz już w publikacji Method in Translation Theory podaje oparte na badaniach konkretnych biografii i poparte przykładami „cechy” tłumacza: nie jest on abstrakcyjnym konstruktem, lecz zbiorem różniących się od siebie, konkretnych, posiadających ciało ludzi - jednostek, mających własne dążenia, cele, lęki i motywacje; tłumacz często nie ogranicza się wyłącznie do pracy przekładowej, niejednokrotnie nie podejmuje jej w pierwszej kolejności z przyczyn zarobkowych, a niekiedy decyduje się ją z różnych powodów porzucić. Podobnie jak w przykładach analizowanych przez Pyma, tak i w biografii Hulki-Laskowskiego możemy dostrzec swoistą wielość tożsamości i masek sygnalizowaną wieloma pseudonimami, pod którymi funkcjonuje tłumacz. Oprócz przywołanego w kontekście publicystycznej krytyki katolicyzmu Franciszka Rosicy Hulka-Laskowski podpisywał swoje teksty prawdziwymi lub fałszywymi inicjałami w zależności od periodyku i tematyki publikowanego tekstu. Pym zwraca także uwagę na fakt, że tłumacze częściej niż przedstawiciele innych zawodów przemieszczają się: znajomość innych języków i kultur sprawia, że mogą między innymi szukać zatrudnienia poza granicami własnego kraju (por. Pym 16o-176). Hulka-Laskowski dzięki znajomości czeskiego i niemieckiego miał możliwość nie tylko kształcić się na uniwersytecie w Heidelbergu, lecz także leczyć się w czeskim sanatorium. Wchodząc w nowe relacje z osobami poznanymi 
na emigracji, zaistniał w sieciach rozmaitych zależności i miał okazję między innymi współtworzyć stosunki dyplomatyczne między Polską a Czechami oraz pośredniczyć w negocjacjach między polskojęzycznymi pracownikami fabryki w Żyrardowie a niemieckojęzycznym dyrektorem.

Taka hybrydyczna, niejednorodna, dynamiczna tożsamość sprzyja manipulacjom i pokusie zatajenia profesji, która nie uchodzi za prestiżową. Badaczy i badaczki przekładu powinny zatem cechować niezwykła uważność i wrażliwość nie tylko na obszary jawnie nieopisane, lecz także na te posiadające silną narrację - nie wyklucza ona istnienia innych, alternatywnych opowieści. Jak zaznacza w eseju Antygony wracaja albo o emancypacji przekładu literackiego Jerzy Jarniewicz:

Tłumacza widzę [...] nie jako pośrednika, stojącego i wiecznie czekającego w drzwiach, ale jako współuczestnika wielu zbiorowości: pisarzy, krytyków, czytelników, wydawców, redaktorów, agentów literackich, grafików itd. Gdybym miał szukać metafor, powiedziałbym, że jest raczej drzewem w lesie niż mostem między brzegami (Jarniewicz 74).

Właśnie w relacjach chciałabym postrzegać tożsamość zarówno Hulki-Laskowskiego, jak i tych wszystkich tłumaczek i tłumaczy - drzew, które dostrzeżemy dopiero wtedy, gdy wejdziemy dalej w las.

\section{| Bibliografia}

Chesterman, Andrew. “The Name and Nature of Translator Studies”. Hermes 42 (2009). S. 13-22.

Jarniewicz, Jerzy. „Antygony wracają albo o emancypacji przekładu literackiego”.

Pluszka, Adam. Wte i wewte. Z tłumaczami o przekładzie. Gdańsk: słowo/ obraz terytoria, 2016. S. 7-16.

Hermans, Theo. Narada języków. Red. M. Heydel, K. Szymańska. Przeł.

Agnieszka Dauksza et al. Kraków: Wydawnictwo Uniwersytetu Jagiellońskiego, 2015.

Hoffman, Eva. Lost in Translation: A Life in a New Language. London: Penguin Books, 1990.

Hulka-Laskowski, Paweł. „Boy - mędrzec”. Wiadomości Literackie 14 (1928). S. 3.

Hulka-Laskowski, Paweł. „O dyskwalifikację tłumaczenia”. Wiadomości Literackie 11 (1928). S. 4. 
Hulka-Laskowski, Paweł. „O dyskwalifikację przekładu «Babuni», do redaktora Wiadomości Literackich”. Wiadomości Literackie 17 (1928). S. 4.

Hulka-Laskowski, Paweł. „Kult niekompetencji recenzentów”. Wiadomości Literackie 40 (1929). S. 4.

Hulka-Laskowski, Paweł. Mój Żyrardów. Z dziejów polskiego miasta i życia pisarza. Żyrardów: Urząd Miejski, 2001.

Kurowska, Elżbieta. Recepcja literatury angielskiej w Polsce 1932-1939. Wrocław: Zakład Narodowy im. Ossolińskich, 1987.

Pym, Anthony. Method in Translation Theory. Manchester: St Jerome Publishing, 1998.

Rosica, Franciszek [Hulka-Laskowski, Paweł]. Polsko, Twa zguba w Rzymie! Chicago: Przebudzenie, 1930.

Sikorska-Kulesza, Jolanta. „ «Skąd się wziął twój braciszek?» Początki dyskusji o wychowaniu seksualnym dzieci i młodzieży na ziemiach polskich”. Kobieta i małżeństwo. Red. A. Żarnowska, A. Szwarc. Warszawa: Wydawnictwo DiG, 2004. S. 25-42.

Stall, Sylvanus. O czem młody człowiek wiedzieć powinien. Przeł. Paweł Hulka-Laskowski. Łódź: Kompas, 1925.

Tys Agnieszka Teresa, Leszczyński Rafał Marcin. „Sprawozdanie z Ogólnopolskiej Konferencji Interdyscyplinarnej: Paweł Hulka-Laskowski - pisarz, religioznawca, bibliofil i pedagog (Łódź, 29-30.05.2015)”. Studia z Teorii Wychowania. T. 6. 3 (2015). S. 219-223.

\section{| Abstrakt}

JOANnA Sobesto

Wszechobecna niewidzialność. Pawła Hulki-Laskowskiego tożsamość tłumacza w kontekście spolszczeń serii amerykańskich książek edukacyjnych "Cnotą a prawdą"

Celem niniejszego artykułu jest spojrzenie na biografię Pawła Hulki-Laskowskiego: teologa, pedagoga, pisarza i dyplomaty z perspektywy jego wieloletniej pracy przekładowej. Hulka-Laskowski, w przeciwieństwie do wielu innych tłumaczek i tłumaczek aktywnych w dwudziestoleciu międzywojennym, do dziś funkcjonuje w obiegowej pamięci, jednak jest to pamięć osobliwa, niemal zupełnie pomijająca działalność przekładową twórcy. Pragnę pokazać, jak kluczowe dla biografii Hulki-Laskowskiego jest doświadczenie przekładu, który kształtuje i odzwierciedla życiowe wybory, postawy i światopogląd. Dowodem może być podjęcie decyzji 
o przekładzie i adaptacji amerykańskich książek dla młodzieży „Cnotą a prawdą”zaskakująco postępowej i nowoczesnej serii zawierającej treści, które do dziś bywają tabuizowane.

Słowa kluczowe: historia przekładu, Paweł Hulka-Laskowski, studia nad tłumaczem, „Mój Żyrardów”, Sylwan Stall

\section{| Abstract}

JoAnna Sobesto

Omnipresent Invisibility. The Identity of the Translator: the Case of Pawel Hulka-Laskowski and His Translation of the Self and Sex Book Series

The main aim of this paper is to look at the biography of Paweł Hulka-Laskowski, a theologian, pedagogue, writer and diplomat, through the perspective of his perennial work as a translator. Unlike his contemporaries - translators active in the interwar period in Poland, Hulka-Laskowski is still well-recognized, the collective memory of him is, however, refracted, often omits his translation work. The paper demonstrates that his experience as a translator was key to his entire professional and private life - both were related to the translation of the series for American teenagers What a Young Man (Woman) Ought to Know.

Keywords: translation history, Paweł Hulka-Laskowski, translator studies, Sylvanus Stall

\section{| Nota o autorze}

Joanna Sobesto - doktorantka na Wydziale Polonistyki Uniwersytetu Jagiellońskiego. Członkini Koła Naukowego Przekładoznawców uj wKoło Tłumaczeń. Obecnie pracuje nad rozprawą doktorską poświęconą politykom przekładu w dwudziestoleciu międzywojennym. Interesuje się studiami nad tłumaczem/tłumaczką oraz historią mówioną.

E-mail: joanna.sobesto@doctoral.uj.edu.pl 
